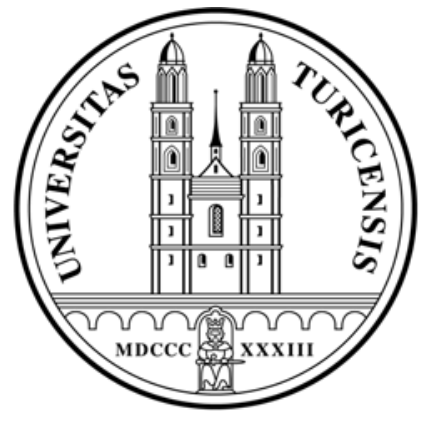

Institute for Empirical Research in Economics

University of Zurich

Working Paper Series

ISSN 1424-0459

Working Paper No. 338

International evidence for return predictability and the implications for long-run covariation of the G7 stock markets

Thomas Nitschka

November 2007 


\title{
International evidence for return predictability and the implications for long-run covariation of the G7 stock markets
}

\author{
Thomas Nitschka*\#
}

Institute for Empirical Research in Economics, University of Zurich

\begin{abstract}
Temporary fluctuations of the U.S. consumption-wealth ratio, cay, predict excess returns on international stock markets at the business cycle frequency. This finding is the reflection of a common, temporary component in national stock markets. Exposure to this common component explains up to 60 percent of the covariation among long-horizon returns on the G7 stock markets for the time period from 1973 to 2005 . The impact of the common component on stock market comovement is particularly pronounced in the period from 1990 to 2005 .
\end{abstract}

JEL classification: E21; G12

Keywords: U.S. consumption-wealth ratio, stock market comovement, stock return predictability

\footnotetext{
*E-mail address: thomas.nitschka@iew.uzh.ch, Phone: +41-(0)44-63-45257.

Postal address: Institute for Empirical Research in Economics, University of Zurich, Zuerichbergstrasse 14, CH-8032 Zuerich

\#This paper is chapter one of my Ph.D. thesis entitled "An asset pricing view on international financial integration". I substantially benefited from numerous discussions with my supervisor Mathias Hoffmann. Moreover, I am especially grateful for comments and remarks by James Nason as well as participants in the $5^{\text {th }}$ IWH Macroeconometric Workshop, the $9^{\text {th }}$ International Conference on Macroeconomic Analysis and International Finance, the $12^{\text {th }}$ Global Finance Conference and the $37^{\text {th }}$ Annual Conference of the Money, Macro and Finance Research Group on former versions of this paper that circulated under the titles "The U.S. consumption-wealth ratio and the predictability of international stock market returns: Evidence from the G7" and "The U.S. consumption-wealth ratio and foreign stock markets: International evidence for return predictability". Research conducted in this paper is partially funded by the Deutsche Forschungsgemeinschaft through SFB 475, project B6: International Allocation of Risk. Any errors and omissions are my own.
} 


\section{Introduction}

If stock markets are perfectly integrated, then they should be driven by the same factors. Harvey (1991), Campbell and Hamao (1992) and Ferson and Harvey (1993) document the importance of global risk factors for the predictability of national stock market returns as well as explaining their cross-sectional differences. In particular, Campbell and Hamao (1992) show that U.S. financial variables, such as the dividend-price ratio (Campbell and Shiller, 1988; Fama and French, 1988) or the relative treasury-bill rate (Campbell, 1991; Hodrick, 1992), do not only predict stock returns on the U.S. but also on the Japanese stock market. Building upon the seminal contributions of Lettau and Ludvigson (2001, 2004), Guo (2006) shows that short-run fluctuations of the U.S. consumption-wealth ratio predict quarterly excess returns on U.S. as well as risk premia on foreign stock markets. These findings leave the impression of a common, temporary component in national stock markets.

Based on these findings, the aim of this paper is twofold. First, I show formally that the U.S. consumption-wealth ratio has to forecast returns on foreign stock markets if the basic logic holds that motivates its use as a predictive variable for U.S. stock returns, thus complementing the recent evidence by Guo (2006) who stops short of providing a formal rationale for his findings. In addition, this paper shows that the predictive power of the U.S. consumptionwealth ratio is most pronounced at the business cycle frequency which is in line with theoretical macroeconomic models that rationalize predictability of stock returns with timevarying risk aversion over the business cycle. ${ }^{1}$ The finding of international stock return predictability by short-run fluctuations of the U.S. consumption-wealth ratio, henceforth abbreviated with cay, stresses the impression of a common, temporary component in national stock markets. However, the implications of a global, stationary stock market component for

\footnotetext{
${ }^{1}$ Time variation in risk aversion can be induced by uninsurable background risks (Constantinides and Duffie, 1996; Heaton and Lucas, 2000a,b), limited stock market participation (Polkovnichenko, 2004; VissingJoergensen, 2002) or the formation of consumption habits (Constantinides, 1990; Campbell and Cochrane, 1999).
} 
the comovement of stock markets have not been considered so far. It is the second main contribution of this paper to fill this gap.

The existing literature on international stock market comovement has taken two extreme points of view as of yet. On the one hand, a wealth of studies focuses on short-term correlations documenting a considerable increase in the short-term (monthly) correlation of global stock market returns in the past two decades (e.g. Longin and Solnik, 1995; Brooks and Del Negro, 2004, 2006; Goetzmann et al., 2005; Berben and Jansen, 2005). On the other hand, the idea that covariation is the reflection of a common permanent component in national stock markets has attracted a lot of attention since the dispute between Kasa (1992) and Richards (1995). Kasa (1992) provides evidence for one common stochastic trend driving the five major stock markets in the long-run using the Johansen cointegration test. Richards (1995) questions the statistical basis of Kasa's analysis and tests empirically some of the restrictions of cointegration on the time-series behaviour of national stock markets. Cointegration among national stock markets requires the predictability of relative stock returns, since a deviation from the common trend by one stock market should be exactly offset by another. For the same reason, cointegrated stock markets imply virtually no long-run gains from international diversification. Richards (1995) provides some evidence for relative stock return predictability. Hence, we cannot rule out the existence of a common, permanent stock market component. In addition, Goetzmann et al. (2005) highlight that -- judged by short-term correlations -- the scope of international diversification among the stock markets of the major economies is very limited.

This paper takes an intermediate position in terms of the frequency (monthly versus several years) at which the comovement of stock market returns is regarded compared to the existing literature on this issue. I argue that the predictive power of U.S. cay for foreign stock market returns reflects the substantial importance of a common, temporary component in explaining 
the evolution of national stock markets at the business cycle frequency. The forecast ability of cay peaks at three-year horizon. I assess how much of the covariation of the G7 stock markets at three-year horizon can be reconciled with the exposure to cay, the mirror image of the common, transitory stock market component.

The main results are easily summarized. Sensitivity to cay explains between 15 to 60 percent of the comovement of three-year returns on the G7 markets over the sample period from the fourth quarter of 1969 to the first quarter of 2005. A visual comparison of the realised threeyear excess returns with the corresponding fitted values from long-horizon regressions reveals that the fit is best in the sample period from 1990 to 2005. For that time period comovement between the G7 stock markets implied by their exposure to the common stationary component is even more pronounced. This finding coincides with the observation of a tremendous rise in cross-border capital flows in the past two decades (e.g. Tesar and Werner, 1995; Hau and Rey, 2004, 2006; Lane and Milesi-Ferretti, 2001) and with firm level evidence of the increasing importance of global shocks for short-term comovement of stock returns in the course of the last twenty years (Brooks and Del Negro, 2006). Thus a higher degree of integration among international stock markets seems to have raised the importance of the common, stationary component for the time-series variation in and comovement between the G7 stock markets.

The remainder of this paper is organized as follows. In the next section, I sketch my slight refinement of the framework of Lettau and Ludvigson $(2001,2004)$ to show formally why the U.S. consumption-wealth ratio should be informative about the future path of foreign stock markets. Section three assesses the cointegration properties of the resulting four variables comprising decomposition of the U.S. consumption-wealth ratio in detail. The predictive power of U.S. cay for excess returns on the MSCI indexes of the G7 is assessed in section four. Section five discusses the role of cay in explaining stock market comovement. Finally, I summarize in section six. The appendix contains details about the construction and sources of 
data used in this paper as well as a variance decomposition of the four variables that form my consumption-wealth ratio proxy with respect to permanent and transitory shocks in the cointegrated system

\section{The relation between U.S. consumption, wealth and expected returns on foreign stock markets}

The main results of Lettau and Ludvigson $(2001,2004)$ convey the notion that time variation in the U.S. consumption-wealth ratio, i.e. time variation in cay, finds its main source in cyclical changes in the market value of U.S. households' stock market wealth. These market value changes are induced by expected returns on stock market wealth mirrored in broad stock indexes. Hence, cay predicts stock returns. I use the remainder of this section to show formally that this reasoning pertains to U.S. households' foreign stock holdings as well, such that U.S. cay has to forecast returns on foreign stock markets. Therefore, I tautologically rewrite the trivariate consumption-wealth ratio approximation of Lettau and Ludvigson (2001, 2004) to explicitly take account of U.S. households' foreign stock holdings.

Following Campbell and Mankiw (1989), Lettau and Ludvigson (2001) regard a representative agent economy in which all wealth is traded.

The representative household faces an intertemporal budget constraint of the form:

$$
W_{t+1}=\left(1+R_{w, t+1}\right)\left(W_{t}-C_{t}\right)
$$

where $W_{\mathrm{t}}$ denotes aggregate wealth (human wealth plus asset wealth) in period t. $C_{\mathrm{t}}$ denotes consumption and $R_{\mathrm{w}, \mathrm{t}+1}$ the net return on aggregate wealth.

Rearranging the budget constraint for the ratio of consumption to wealth and taking a loglinear approximation around the mean consumption-wealth ratio under the assumption that this mean is covariance stationary leads to the following law of motion for the log consumption-wealth ratio. 


$$
c_{t}-w_{t}=E_{t} \sum_{i=1}^{\infty} \rho_{w}^{i}\left(r_{t+i}^{w}-\Delta c_{t+i}\right)
$$

Lower-case letters denote natural logarithms throughout the chapter, $\Delta$ denotes the difference operator.

In order to make Equation (2) empirically tractable, Lettau and Ludvigson (2001, 2004) decompose aggregate wealth into its components asset and human wealth and loglinearise around the long-run mean of the ratio of human and asset wealth which leads to

$$
w_{t} \approx v a_{t}+(1-v) h_{t}
$$

with $v$ interpretable as average share of asset wealth in aggregate wealth, $a_{\mathrm{t}}$, log asset wealth and $h_{\mathrm{t}}, \log$ human wealth such that the log consumption-wealth obeys

$$
c_{t}-v a_{t}-(1-v) h_{t}=E_{t} \sum_{i=1}^{\infty} \rho_{w}^{i}\left(v r_{t+i}^{a}+(1-v) r_{t+i}^{h}-\Delta c_{t+i}\right)
$$

decomposing the return on aggregate wealth, $r_{t}{ }^{w}$,accordingly (Campbell, 1996).

I further decompose asset wealth into foreign stocks held by U.S. households, abbreviated with $f s_{t}$, and the rest of asset wealth (U.S. stocks, real estate, etc.) which I will refer to as domestic asset wealth, $d a w_{t}$. A loglinear approximation of asset wealth around the foreign equity to domestic asset wealth ratio yields

$$
a_{t} \approx \lambda_{t} d a w_{t}+\left(1-\lambda_{t}\right) f s_{t}
$$

with $\lambda_{t}$ the (time-varying) share of domestic asset wealth in U.S. households' asset wealth and $1-\lambda_{t}$ the share of foreign equity. ${ }^{2}$ As the shares of domestic asset wealth and foreign equity are observable, I do not require to assume constant foreign equity and domestic asset wealth shares which would be more than inappropriate as figure 1 shows. Figure 1 presents the share of foreign equity in U.S. households' asset wealth (vertical axis) over time from 1952 to 2005 (horizontal axis).

\footnotetext{
${ }^{2}$ I thank Mathias Hoffmann for suggesting this course of analysis.
} 
Apparently, the share of foreign equity in U.S. asset wealth is small in absolute terms but experienced a substantial increase since the mid-1980s. Since $\lambda_{t}$ could also be interpreted as a measure of home bias in U.S. asset wealth, this figure visualizes the decline in home bias as documented in Lane and Milesi-Ferretti (2001) for a large set of countries.

Combining (4) with (5) gives

$$
w_{t} \approx v\left(\lambda_{t} d a w_{t}+\left(1-\lambda_{t}\right) f s_{t}\right)+(1-v) h_{t}
$$

A loglinear approximation of the gross return on asset wealth, $r_{t}^{a}$, with respect to foreign equity and domestic asset wealth follows the same pattern as the decomposition of the asset wealth components (Campbell, 1996), such that we obtain $r_{t}^{a}=\lambda_{t} r_{t}^{\text {daw }}+\left(1-\lambda_{t}\right) r_{t}^{f s}$ and hence

$$
\begin{aligned}
& c_{t}-v\left(\lambda_{t} \text { daw }_{t}+\left(1-\lambda_{t}\right) f_{s_{t}}\right)+(1-v) h_{t} \\
& =E_{t}\left\{\sum_{i=1}^{\infty} \rho_{w}^{i}\left[\left(v\left(\lambda_{t} r_{t+i}^{d a w}+\left(1-\lambda_{t}\right) r_{t+i}^{f s}\right)+(1-v) r_{t+i}^{h}\right)-\Delta c_{t+i}\right]\right\}
\end{aligned}
$$

by plugging (6) into (2).

Multiplying out gives

$$
\begin{aligned}
& c_{t}-v f S_{t}-v\left(\lambda_{t}\left(d a w_{t}-f S_{t}\right)\right)+(1-v) h_{t} \\
& =E_{t}\left\{\sum_{i=1}^{\infty} \rho_{w}^{i}\left[\left(v r_{t+i}^{f s}-v\left(\lambda_{t}\left(r_{t+i}^{d a w}-r_{t+i}^{f s}\right)\right)+(1-v) r_{h, t+i}\right)-\Delta c_{t+i}\right]\right\}
\end{aligned}
$$

However, (8) cannot be employed for empirical purposes because one part of aggregate wealth, human wealth, is unobservable. I follow Lettau and Ludvigson (2001) and assume labour income to represent the dividend paid from human wealth and thus its non-stationary component to overcome this obstacle. Then log human wealth, $h_{\mathrm{t}}$, obeys

$$
h_{t}=\kappa+y_{t}+z_{t}
$$

with $y_{t}, \log$ labour income, $\kappa$, a constant term and a covariance stationary term $z_{t}$. Plugging (9) into (8) and assuming that the return on labour income equals the return on human wealth gives 


$$
\begin{aligned}
& c_{t}-v f s_{t}-v\left(\lambda_{t}\left(d a w_{t}-f s_{t}\right)\right)+(1-v) y_{t} \\
& =E_{t}\left\{\sum_{i=1}^{\infty} \rho_{w}^{i}\left[\left(v r_{t+i}^{f s}-v\left(\lambda_{t}\left(r_{t+i}^{d a w}-r_{t+i}^{f s}\right)\right)+(1-v) \Delta y_{t+i}\right)-\Delta c_{t+i}\right]+(1-v) z_{t+i}\right\}
\end{aligned}
$$

According to (10), $c_{t}$, log consumption, $f_{s_{t}}$, log foreign equity, $\lambda_{t}\left(d a w_{t}-f_{s_{t}}\right)$, the interaction term of foreign equity with domestic asset wealth and the (time-varying) share of domestic asset wealth in U.S. households' asset wealth and $y_{t}$, log labour income, cointegrate provided they are integrated of order one, I(1). Hence, time variation of the consumption-wealth ratio, i.e. a temporary deviation from the common trends, mirrors either returns on (changes of) foreign equity holdings, returns on the interaction term, changes of labour income or consumption growth or some combination of those. Admittedly, the interaction term is hard to interpret economically and so are returns on this variable. However, the only purpose of this decomposition of the consumption-wealth ratio is to examine the error-correction properties of foreign stock holdings of U.S. households in the cointegrated relation between consumption and aggregate wealth to provide a formal rationale of the predictive power of U.S. cay for foreign stock market returns.

\section{Empirical Evidence: Cointegration, Error Correction and Variance Decomposition}

If foreign stock holdings adjust temporary deviations from the common trend among consumption and aggregate wealth, then U.S. cay has to mirror future returns on foreign stock markets. This is the implication of the present value representation (10) of the U.S. consumption-wealth ratio.

This section is thus devoted to assess the cointegration properties of my four variables comprising loglinear proxy of the U.S. consumption-wealth ratio. All variables are quarterly, per capita, real in billions of chain-weighted 2000 U.S. dollars and transformed to natural logarithms for the sample period from the second quarter of 1952 to the first quarter of 2005. 
Labour income and consumption are approximated as proposed by Lettau and Ludvigson (2001, 2004). As pointed out by Lettau and Ludvigson (2001) as well as Rudd and Whelan (2006), the budget constraint (1) refers to total personal consumption flows. Since we do not observe consumption flows we rely on expenditures as best proxy. Lettau and Ludvigson (2001) follow Blinder and Deaton (1985) and assume that the log consumption expenditure on non-durables and services consumption is a constant multiple of the logarithm of total consumption expenditure. Rudd and Whelan (2006) provide evidence that the relation between $\log$ non-durable and services consumption and log total personal consumption expenditure is not constant over time. However, Lettau and Ludvigson (2004) argue that durable consumption expenditure represents rather replacements or additions to an existing stock than a service flow from the stock of durable goods and hence is better described as wealth which is the view I follow in this paper. The choice of consumption approximation will have an impact on the estimates of the cointegration coefficients as e.g. discussed in Hoffmann (2006a) but it turns out that the qualitative results in terms of error correction properties and forecasting power for stock returns remain unaltered, even though the by now common assumption of a constant relation between total consumption and expenditures on non-durables and services is debatable in this context.

Unit root tests show that the four variables under consideration are I(1), which conveys the notion that my four-variable approximation of the log consumption-wealth ratio should cointegrate. $^{3}$ Table 1 displays results of the Johansen cointegration test, critical values for Trace and L-max test as well as the test statistics for both of the tests.

Akaike (AIC) and Schwartz (SIC) information criteria suggest an appropriate lag length of one quarter for the vector autoregressive representation (VAR) of the four variables.

According to the test statistics, the null of no cointegration for the relation between nondurables and services consumption expenditure excluding clothing and shoes, foreign equity

\footnotetext{
${ }^{3}$ Unit root tests are not reported to conserve space
} 
holdings, the interaction term of foreign equity with domestic asset wealth and labour income is rejected at 90 percent confidence level. Hence, the test results can be interpreted in favour of one cointegrating relation among the four variables under consideration.

The cointegrating relation (10) imposes the restriction that the cointegration coefficients of foreign equity holdings and the interaction term of foreign equity with domestic asset wealth should equalize. I assess these restrictions by estimating the cointegration vector via a dynamic least squares regression (DOLS) proposed by Stock and Watson (1993). OLS estimates of cointegrated variables converge to their true value with the sample size rather than with the square root of the sample size (Stock, 1987). Thus, these estimates are "superconsistent" and simple OLS provides consistent point estimates. But the error terms of the individual time-series variables could be correlated with each other. Hence, the OLS estimates are consistent but potentially biased. The DOLS estimate equation takes the following form:

$$
\begin{aligned}
& c_{t}=\alpha+\beta_{f e} f s_{t}+\beta_{d a w}\left(\lambda_{t-i}\left(\operatorname{daw}_{t-i}-f s_{t-i}\right)\right)+\beta_{y} y_{t} \\
& +\sum_{i=-k}^{k} b_{f s, i} \Delta f s_{t-i}+\sum_{i=-k}^{k} b_{d a w, i} \Delta\left(\lambda_{t-i}\left(d a w_{t-i}-f s_{t-i}\right)\right)+\sum_{i=-k}^{k} b_{y, i} \Delta y_{t-i}+\varepsilon_{t}
\end{aligned}
$$

Estimation of the cointegration coefficients, $\beta_{\mathrm{i}}$ with $\mathrm{i}=f s, \lambda(d a w-f s), y$ gives the cointegration vector $\hat{\beta}$ if the coefficient on consumption (here: non-durables and services) is normalised to unity. ${ }^{4}$ Newey-West corrected t-statistics appear in parenthesis (Newey and West, 1987). The coefficients of differences in lead or lag are omitted.

$$
\hat{\beta}=\left[\begin{array}{llll}
1 & -\underset{(8.77)}{0.22 f s_{t}} & -0.21\left(\lambda_{t}\left(d a w_{t}-f s_{t}\right)\right) & -\underset{(8.07)}{0.63 y_{t}}
\end{array}\right]^{\prime}
$$

Note that the cointegration coefficient estimates of foreign equity and log domestic asset wealth minus log foreign equity are approximately the same as required by the decomposition of the consumption-wealth ratio.

\footnotetext{
${ }^{4}$ The estimates do not vary much from one to eight leads and lags. Here eight leads and lags are employed. Johansen's maximum likelihood procedure provides very similar estimates. Furthermore, the cointegration coefficients sum to roughly unity if total consumption is employed in the estimation (not reported).
} 
Engle and Granger (1987) point out that for every cointegrating relation an error-correction representation exists. Here, the error correction properties of the cointegrated system should reveal if foreign equity adjusts a temporary deviation from the common trend among consumption and aggregate wealth which would rationalize the predictive power of cay for foreign stock market returns.

The vector error correction representation (VECM) of $\boldsymbol{x}_{\mathrm{t}}=\left[c_{\mathrm{t}}, f s_{\mathrm{t}}, \lambda_{\mathrm{t}}\left(d a w_{\mathrm{t}^{-}}-f s_{\mathrm{t}}\right), y_{\mathrm{t}}\right]^{\prime}$ is

$$
\Gamma(L) \Delta x_{t}=\alpha \boldsymbol{\beta}^{\prime} x_{t-1}+\varepsilon_{t}
$$

in which $\Delta \boldsymbol{x}_{\mathrm{t}}=\left[\Delta c_{\mathrm{t}}, \Delta f_{s_{\mathrm{t}}}, \Delta\left(\lambda_{\mathrm{t}}\left(d a w_{\mathrm{t}}-f s_{\mathrm{t}}\right)\right) \Delta y_{\mathrm{t}}\right]^{\prime}$ is the vector of first differences and $\boldsymbol{x}_{\mathrm{t}-1}$ the vector of lagged levels, $\boldsymbol{\alpha} \equiv\left[\alpha_{\mathrm{c}}, \alpha_{\mathrm{fs}}, \alpha_{\mathrm{daw}-\mathrm{fs}}, \alpha_{\mathrm{y}}\right]^{\prime}$ is the vector of error correction coefficients. $\Gamma(\boldsymbol{L})$ denotes a (4-by-4) matrix in the lag operator and $\hat{\boldsymbol{\beta}}=\left[1,-\beta_{f s},-\beta_{d a w-f s},-\beta_{y}\right]^{\prime}$ represents the vector of the above estimated cointegration coefficients when non-durables and services consumption expenditures are used as consumption proxy. The (4-by-1) vector of shocks in the cointegration relation is represented by $\boldsymbol{\varepsilon}_{\mathrm{t}}$ with covariance matrix $\Omega$. Lower-case letters in bold face denote vectors, bold upper-case letters represent matrices.

The term $\hat{\boldsymbol{\beta}}^{\prime} \boldsymbol{x}_{\boldsymbol{t}-1}$ gives the cointegration residual, $\boldsymbol{\alpha}$ is the adjustment vector that displays what variables adjust a deviation from the common trend. If $\boldsymbol{x}_{\mathrm{t}}$ is cointegrated, at least one of the adjustment coefficients $\alpha_{\mathrm{c}}, \alpha_{\mathrm{fs}}, \alpha_{\mathrm{daw}-\mathrm{fs}}$ or $\alpha_{\mathrm{y}}$ has to take values different from zero in the errorcorrection representation. Table II reports VECM coefficient estimates. The lag length of one has been chosen according to Akaike and Schwartz information criteria. T-statistics of the coefficient estimates are in parenthesis. I focus on the adjustment coefficients in the last row of table 2 .

The adjustment coefficient estimates of both of the asset wealth components, foreign equity and foreign equity interacted with domestic asset wealth are statistically different from zero which mirrors the responsibility of the two components for the error correction in the cointegrated system. 
From (10) error correction through foreign equity implies that the cointegration residual, cay, mirrors expected returns on foreign equity and hence on foreign stock markets which thus explains the findings of Guo (2006).

Error correction through foreign equity holdings implies that the market value of foreign stocks varies mainly in response to transitory shocks. I follow Hoffmann (2001) in identifying permanent and transitory shocks in the cointegrating system to quantify their contribution to the forecast error variance of the level of consumption, foreign stock holdings, domestic asset wealth interacted with foreign equity and labour income.

As I regard a cointegrated system with four variables and one single cointegrating relation, there are three permanent shocks representing the innovations to the three common trends and one single transitory shock (Stock and Watson, 1988). Identification is achieved by inverting the vector error correction representation of $\boldsymbol{x}_{\mathrm{t}}=\left[c_{\mathrm{t}}, f_{\mathrm{t}}, \lambda_{\mathrm{t}}\left(d a w_{\mathrm{t}}-f_{s_{\mathrm{t}}}\right), y_{\mathrm{t}}\right]^{\prime}$ into a multivariate Beveridge-Nelson moving average representation in terms of the reduced form disturbances (Beveridge and Nelson, 1981), which is given by

$$
\boldsymbol{x}_{t}=\boldsymbol{C}(1) \sum_{i=0}^{t} \varepsilon_{i}+\boldsymbol{C}^{*}(\boldsymbol{L}) \varepsilon_{t}
$$

The first term on the right-hand side of (13) represents the random walk and the second term the stationary component of $\boldsymbol{x}_{\boldsymbol{t}}$.

Johansen (1995) shows that $\boldsymbol{C}(\mathbf{1})$ can be identified with the parameters of the VECM, such that

$$
C(1)=\beta_{\perp}\left(\alpha_{\perp}^{\prime} \Gamma(1) \beta_{\perp}\right)^{-1} \alpha_{\perp}^{\prime}
$$

where $\boldsymbol{\beta}_{\perp}, \boldsymbol{\alpha}_{\perp}$ are the orthogonal complements of $\boldsymbol{\alpha}$ and $\boldsymbol{\beta}$. The Granger representation theorem implies that $\alpha$ and $\beta$ satisfy $\boldsymbol{\beta}^{\prime} \boldsymbol{C}(\mathbf{1})=0$ and $\boldsymbol{C}(\mathbf{1}) \boldsymbol{\alpha}=0$.

The common trends, $\pi_{\mathrm{t}}$, thus are

$$
\pi_{t}=\boldsymbol{\alpha}_{\perp}^{\prime} \sum_{i=0}^{t} \varepsilon_{i}=\sum \eta_{t}
$$


Let $\eta_{t}^{P}=\boldsymbol{\alpha}_{\perp}^{\prime} \varepsilon_{t}$ denote the permanent shocks to the cointegrated system and $\eta_{t}^{T}=\boldsymbol{\alpha}^{\prime} \boldsymbol{\Omega}^{-1}$ the transitory shock if it is orthogonal to the permanent shocks. Hence, the structural permanent shocks and the structural transitory shock are identified via

$$
\boldsymbol{\eta}_{\boldsymbol{t}}=\boldsymbol{S} \boldsymbol{\varepsilon}_{t}
$$

with $\boldsymbol{\eta}_{t}=\left(\begin{array}{c}\eta_{t}^{P} \\ \eta_{t}^{T}\end{array}\right)$ and $\boldsymbol{S}=\left(\begin{array}{c}\left(\boldsymbol{\alpha}_{\perp}^{\prime} \boldsymbol{\Omega} \boldsymbol{\alpha}_{\perp}\right)^{1 / 2} \boldsymbol{\alpha}_{\perp}^{\prime} \\ \left(\boldsymbol{\alpha}^{\prime} \boldsymbol{\Omega} \boldsymbol{\alpha}\right)^{1 / 2} \boldsymbol{\alpha}^{\prime} \boldsymbol{\Omega}^{-1}\end{array}\right)$ to make sure that $\eta_{t}^{P}$ and $\eta_{t}^{T}$ have unit variance.

With this identification it is straightforward to quantify the contribution of the three permanent shocks and the single transitory shock to the forecast error variance of the four cointegrated variables.

Table 3 presents the decomposition of the forecast error variance of the levels of $c, f s, \lambda(d a w-$ $f s$ ) and $y$ into the components that can be attributed to the three permanent shocks combined and to the transitory shock. I identify the transitory shock as orthogonal to the permanent shocks. The top panel reports variance decompositions if statistically insignificant adjustment coefficient estimates are set to zero as recommended by Gonzalo and $\mathrm{Ng}$ (2001). The bottom panel displays variance decompositions if all adjustment coefficients are set to their estimated values.

The transitory shock should have the strongest effect on the forecast error variance of the asset wealth components because their adjustment coefficient estimates are statistically significant. This implies that both of the variables participate in the correction of a temporary deviation from the common trends among $c, f s, \lambda(d a w-f s)$ and $y$ and hence should be primarily driven by the transitory shock. The variance decompositions mirror exactly this reasoning. Note also that the impact of the transitory shock on the variance of foreign equity is stronger than on domestic asset wealth which is in line with the magnitude of the error correction coefficient estimates. The foreign equity adjustment coefficient is larger than that of domestic asset wealth, i.e. the transitory shock has to have a stronger impact on foreign equity than on domestic asset wealth. 
Consumption and labour income do not participate in the error correction mechanism. Their adjustment coefficients are statistically indistinguishable from zero, which means that both of the variables should be predominantly driven by the permanent shocks. Variance decompositions for consumption and labour income support this reasoning. Almost all of the variation in consumption and labour income can be attributed to the three permanent shocks at any time horizon.

\section{U.S. cay and excess returns on foreign stock markets}

The forecast ability of cay for stock market returns has raised continuous debates. Brennan and Xia (2005) are concerned that the predictive power of cay is due to a look-ahead bias because the cointegration parameters used to estimate cay are estimated over the full sample period which explains why cay does not predict stock returns out-of-sample but only insample. Additionally, Hahn and Lee (2003) argue that the forecasting power of cay is largely driven by a time trend.

In their reply to this critique, Lettau and Ludvigson $(2005 \mathrm{a}, \mathrm{b})$ show that the success of cay in explaining excess returns does not necessarily involve estimation of the cointegration coefficients. Hence, look-ahead bias by estimating the cointegration coefficients is not likely a reason for the predictive power of cay. Moreover, they argue that if one estimates the cointegration coefficients, it would be inappropriate not to use information from the full sample period since cointegration is a long-run phenomenon. Hoffmann (2006b) shows that the Lettau and Ludvigson (2001a, 2004) framework implies two cointegrating relationships that are not discovered by standard cointegration tests because of deterministic trends and a structural break. However, he also shows that the predictive power of cay is still a salient feature of the data if one properly takes account of the before mentioned issues. 
I thus focus on the in-sample predictability of long-horizon excess returns on the Morgan Stanley Capital International (MSCI) indices of the G7 stock markets. Since cay is only observed at quarterly frequency, I calculate end-of-quarter returns from monthly data on the MSCI G7 indexes denominated in U.S. dollar. Following Campbell and Hamao (1992), the U.S. three-month t-bill rate is used to obtain excess returns. Table 4 reports estimates of regressions of the form

$$
r_{t+h}^{i, e}=\alpha_{h}+\beta_{h} c a y_{t}+\varepsilon_{t+h}
$$

with $r_{t+h}^{i, e}$ the $\log$ excess return on the MSCI stock index of country $i$ at time horizon $t+h$. Newey-West corrected t-statistics appear below the regressor estimates (Newey and West, 1987). $\mathrm{R}^{2}$ reports the adjusted $\mathrm{R}^{2}$. Bold faces highlight significant estimates.

Apart from Japan all stock market excess returns of the remaining G7 economies are predicted by cay which corroborates Guo (2006). The peak of the forecast ability of cay is reached at time horizons between 12 and 16 quarters consistent with theoretical macroeconomic models that motivate time-varying risk premia with time variation in risk aversion (Constantinides, 1990; Constantinides and Duffie, 1996; Campbell and Cochrane, 1999; Heaton and Lucas, 2000a,b; Vissing-Joergensen, 2002; Polkovnichenko, 2004).

The $\mathrm{R}^{2}$ statistics display that substantial proportions in the variation of foreign stock market returns are explained by cay. The highest $\mathrm{R}^{2}$ statistics for foreign stock markets is 0.37 for the United Kingdom.

Evidence for predictability of stock returns from long-horizon regressions in relatively small samples should be regarded with healthy scepticism since the standard errors of the regressor estimates rely on asymptotic distribution theory (see e.g. Valkanov (2003) and the literature surveyed therein). However, Hodrick (1992) shows that a large amount of long-horizon predictability is consistent with a small portion of short-run predictability.

Here, for four of seven countries, U.S. cay predicts the one-quarter excess returns statistically significantly. Guo (2006) examines a wider cross-section of countries at the one-quarter 
horizon and finds most of developed economies' stock market returns to be explained by cay. Hence, it seems justified to conclude that U.S. cay predicts foreign stock market returns.

The (conventional) long-horizon regressions conducted in this section serve to illustrate at what time horizon the predictive power of cay for foreign stock market returns reaches its peak. As emphasized above, the peak of predictability at three and four year horizon is consistent with theoretical macroeconomic models.

When stock market excess returns denominated in local currency are considered, the qualitative results remain the same. Moreover, the results do not change if I employ the respective countries' short-term interest rate to obtain excess returns (not reported).

The forecast ability of U.S. cay for risk premia on foreign stock markets is interesting in the light of recent studies that examine the predictive power of national consumption-wealth ratios for national stock markets. Evidence by Fernandez-Corugedo et al. (2003), Fisher and Voss (2003), Tan and Voss (2004) and Ioannidis et al. (2006) suggests that short-run fluctuations in national consumption-wealth ratios predict national stock market returns. However, these studies focus on Anglo-Saxon countries while Hamburg et al. (2007) present evidence that German cay does not predict German stock market returns but macroeconomic variables as the unemployment rate. The predictive power of a Japanese consumption-wealth ratio for national stock market returns is virtually zero as well (Nagayasu, 2006). Obviously, U.S. cay explains risk premia on both Anglo-Saxon and European countries' stock markets. The explanatory power of cay for excess returns on the G7 stock markets seems to be substantial. Recent empirical studies (Hau and Rey, 2004, 2006; Lane and Milesi-Ferretti, 2001) emphasize that cross-border equity flows have increased tremendously in the last two decades. Hence the explanatory power of cay should be especially pronounced since the mid1980s. In order to visualize this point, figures 2 to 8 present realised three-year excess returns on the G7 stock markets together with the corresponding fitted values from regression (17). The overall picture that emerges is that cay captures the three-year variation in long-horizon 
excess returns reasonably well, especially in the sample period from 1990 to 2005 thus corroborating the conjecture made above.

As suggested by the cointegration framework, the U.S. consumption-wealth ratio is informative about the future path of foreign stock markets. But the question remains if the forecast ability of cay survives once a country-specific predictor of stock returns, e.g. the respective national dividend-price ratio, is considered as an additional forecast variable in the long-horizon regressions.

I construct national dividend-price ratios from MSCI total return and price indexes as described in Kasa (1992) to run regressions of the form

$$
r_{t+h}^{i, e}=\alpha_{h}+\beta_{h, c a y} c a y_{t}+\beta_{h, d p}\left(d_{t}^{i}-p_{t}^{i}\right)+\varepsilon_{t+h}
$$

with $d_{t}^{i}-p_{t}^{i}$ the $\log$ dividend-price ratio of country $i$. Table 5 presents the results.

It is apparent that the forecast ability of cay is not materially affected by the presence of the national dividend-price ratio as additional regressor. Noteworthy is the finding that the Japanese, British and German dividend-price ratio predict excess returns on the respective national stock market. While the British and German dividend-price ratio as well as cay jointly predict long-horizons returns on the respective MSCI index, the Japanese dividendprice ratio is the only variable with forecast ability of excess returns on the Japanese stock market.

These results corroborate that a common temporary component in national stock markets exists. Its importance is mirrored in the predictive power of cay for foreign stock returns. The impact of the common component on international stock markets is highest at the business cycle frequency. In addition, cay forecasts risk premia on foreign stock markets even in the presence of country-specific predictors of stock returns. 


\section{Covariation of returns}

As Campbell and Hamao (1992) point out, a single variable that predicts stock returns on several national stock markets can be interpreted as the reflection of a common stock market component. Furthermore, the sensitivity of national stock markets to this common component should explain covariation among these markets.

Following this logic, the predictive power of U.S. cay seems to reflect a temporary component common to national stock markets as it explains a considerable fraction of the variation in risk premia on the G7 stock markets. Hence we should also obtain information about the degree of covariation between the $\mathrm{G} 7$ stock markets by their sensitivity to cay.

Information about stock market comovement should thus be inferred from

$$
\boldsymbol{r}=\boldsymbol{\gamma c a y}+\boldsymbol{\varepsilon}
$$

where $\boldsymbol{r}$ is the N-by-1 vector of excess returns on the G7 markets at a particular time horizon with $\mathrm{N}$ the number of returns, cay reflects the common temporary component, $\gamma$ denotes the N-by-1 vector of coefficients from the long-horizon regressions (17) at the respective time horizon, and $\varepsilon$ denotes the N-by-1 vector of the corresponding error terms.

Hence, the covariance of the excess returns obeys

$$
\operatorname{var}(\boldsymbol{r})=\boldsymbol{\gamma \gamma ^ { \prime }} \operatorname{var}(c a y)+\operatorname{var}(\varepsilon)
$$

so that we can measure covariation implied by the exposure to cay with a multivariate " $R^{2}$ " measure of the form

$$
\mathbf{R}^{2}=\mathbf{I}-\frac{\operatorname{var}\left(\varepsilon_{i, j}\right)}{\operatorname{var}\left(\boldsymbol{r}_{i, j}\right)}
$$

I focus on the covariation between the 12-quarter excess returns on the MSCI stock indexes of the G7 economies as the predictive power of cay and hence the influence of the common component peaks at that horizon. Table 6 presents my measure of covariation for the threeyear excess returns of the G7 economies for the sample period from 1973 to 2005 . The values 
on the diagonal reflect the $R^{2}$ statistics from the long-horizon regressions while the offdiagonal elements give the pairwise amount of covariation among the three-year returns on the G7 stock markets implied by their exposure to cay. As an example, consider the row GER and its intersection with the column FRA. The number of 0.27 in this cell says that 27 percent of the common movement in the French and German three-year stock returns can be rationalized by their sensitivity to cay, the mirror image of the common temporary component.

Not surprisingly, little of the Japanese stock market's covariation with the other G7 economies is captured by the common component. It varies between one and 23 percent with regard to the U.S. But cay explains between 15 to 60 percent of the covariation between 12quarter excess returns on the remaining G7 stock markets. Interestingly, the comovement among the three core European countries is less pronounced than their common movement with the U.S.

There is still some covariation between the G7 markets that is unexplained which could be caused by a common permanent component in international stock markets or due to countryspecific effects as suggested by Richards (1995). Nonetheless, table 6 highlights the importance of the international stock market component in explaining the covariation of national stock markets at the business cycle frequency.

Furthermore, this finding sheds light on the degree of integration of the G7 stock markets. Comovement caused by a common component can be interpreted as reflection of integration of capital markets (Campbell and Hamao, 1992). The amount of covariation explained by the common stock market component is not negligible which is suggestive of relatively well integrated stock markets among the G7.

In addition, figures 2 to 8 convey the notion that the importance of the common component for the covariation of the G7 returns is particularly pronounced in the sample period from 
1990 to 2005. Table 7 reports the amount of covariation explained by cay for this sample period.

Consistent with the visual impression from figures 2 to 8 the explanatory power of the international stock market component for comovement of the G7 markets is considerably stronger than in the full sample. This finding does even pertain to Japan vis-à-vis the other G7 economies. The common temporary component explains up to 70 percent of the covariation among the G7 stock markets since the 1990s and leaves the impression of increased market integration among the major industrialized countries.

\section{Summary}

This paper corroborates and extends earlier evidence for the existence of a common temporary component in international stock markets that is reflected in the predictive power of short-run variations in the U.S. consumption-wealth ratio, cay, for excess returns on foreign stock markets at the business cycle frequency. This common component is responsible for 15 to 60 percent of the covariation between 3-year excess returns on the G7 stock markets in the period from 1969Q4 to 2005Q1. This finding is most pronounced for the sample period from 1990 to 2005 where we date the onset of financial globalisation. Taken together these findings are suggestive of an increase in the importance of the common stock market component for the time series variation in and covariation between major stock markets. The latter result ties in with empirical studies that highlight the growing importance of global factors for the comovement of national stock markets at relatively high (monthly) frequency (Brooks and Del Negro, 2006).

In addition, this paper provides a formal rationale for the predictive power of U.S. cay for excess returns on foreign stock markets. The market value of U.S. households' foreign equity 
holdings changes in response to expected returns on foreign stocks to adjust deviations from the common trend among consumption and aggregate wealth in the U.S. 


\section{Appendix : Data construction}

U.S. household stock market wealth includes directly held equity shares at market value and indirectly held equity shares namely life insurance companies' holdings, private pension fund holdings, state and local government as well as federal government fund holdings and households' mutual fund holdings. Annual data is published in the supplemental table B.100e in the Z1 Flow of Funds Accounts of the Federal Reserve Board. I construct quarterly stock market wealth from Flow of Funds tables L.213 and L.214 to calculate foreign equity holdings at quarterly frequency.

U.S. household foreign stock holdings are calculated with help of Z1 Flow of Funds table L.213 which provides details about equity issues and holdings at market value. Corporate equity issues at market value include holdings of foreign issues by U.S. residents inclusive American Depositary Receipts. I assume that the share of rest-of-the-world equity holdings in total corporate equity holdings is the same as the share of rest-of-the-world equity holdings in U.S. households' equity holdings because U.S. households hold either directly or indirectly roughly $90 \%$ of total corporate equity issues.

U.S. household domestic asset wealth is the difference between household net worth, Z1 Flow of Funds table B.100, line 42, and the market value of U.S. household foreign stock holdings. 


\section{References}

Berben R.P. and Jansen W.J. 2005. Comovement in international equity markets: A sectoral view. Journal of International Money and Finance 24: 832-857.

Beveridge S. and Nelson C.R. 1981. A new approach to decomposition of economic time series into permanent and transitory components with particular attention to the measurement of the business cycle. Journal of Monetary Economics 7: 151-174.

Brennan M. and Xia Y. 2005. tay's as good as cay. Finance Research Letters 2:1-14.

Brooks R. and Del Negro M. 2004. The rise in comovement across national stock markets: market integration or IT bubble. Journal of Empirical Finance 11: 659-680.

Brooks R. and Del Negro M. 2006. Firm-Level Evidence on International Stock Market Comovement. Review of Finance 10: 69-98.

Campbell J.Y. 1991. A Variance Decomposition for Stock Returns. Economic Journal 101: 157-179.

Campbell J.Y. 1996. Understanding Risk and Return. Journal of Political Economy 104: 298345.

Campbell J.Y. and Cochrane J.H. 1999. By Force of Habit: A Consumption-Based Explanation of Aggregate Stock Market Behaviour. Journal of Political Economy 107: 205251.

Campbell J.Y. and Hamao Y. 1992. Predictable Stock Returns in the United States and Japan: A Study of Long-Term Capital Market Integration. Journal of Finance 47: 43-69.

Campbell J.Y. and Mankiw N.G. 1989. Consumption, income and interest rates: Reinterpreting the time series evidence. in: Blanchard O., Fisher S. (eds.), NBER Macroeconomics Annual. MIT Press, Cambridge MA.

Campbell J.Y. and Shiller R.J. 1988. The Dividend Price Ratio and Expectation of Future Dividends and Discount Factors. Review of Financial Studies 1: 195-227.

Constantinides G.M. 1990. Habit Formation: A Resolution of the Equity Premium Puzzle. Journal of Political Economy 98: 519-543.

Constantinides G.M. and Duffie D. 1996. Asset Pricing with Heterogeneous Consumers. Journal of Political Economy 104: 219-240.

Engle R.F. and Granger C.W.J. 1987. Co-Integration And Error Correction: Representation, Estimation and Testing. Econometrica 55: 251-276.

Fama E.F. and French K.R. 1988. Dividend Yields and Expected Stock Returns. Journal of Financial Economics 22: 3-25.

Fernandez-Corugedo E., Price S. and Blake A. 2003. The dynamics of consumer's expenditure: the UK consumption ECM redux. Bank of England working paper 204. 
Ferson W.E. and Harvey C.R. 1993. The Risk and Predictability of International Stock Returns. Review of Financial Studies 6: 527-566.

Fisher L.A. and Voss G.M. 2004. Consumption, Wealth and Expected Stock Returns in Australia. Economic Record 80: 359-372.

Goetzmann W.N., Li L. and Rouwenhorst G.K. 2005. Long-Term Global Market Correlations. Journal of Business 78: 1-24.

Gonzalo J. and Ng S. 2001. A Systematic Framework for Analyzing the Dynamic Effects of Permanent and Transitory Shocks. Journal of Economic Dynamics and Control 25: 15271546.

Guo H. 2006. The Risk-Return Relation in International Stock Markets. The Financial Review 41: $565-587$.

Hahn J. and Lee H. 2003. Interpreting the predictive power of the consumption-wealth ratio. Journal of Empirical Finance 13: 183-202.

Hamburg B., Hoffmann M. and Keller J. 2007. Consumption, Wealth and Business Cycles: Why is Germany different? forthcoming Empirical Economics

Harvey C.R. 1991. The World Price of Covariance Risk. Journal of Finance 46: 111-157.

Hau H. and Rey H. 2004. Can Portfolio Rebalancing Explain the Dynamics of Equity Returns, Equity Flows, and Exchange Rates? American Economic Review P\&P 94: 126-133.

Hau H. and Rey H. 2006. Exchange Rates, Equity Prices and Capital Flows. Review of Financial Studies 19: 273-317.

Heaton J. and Lucas D. 2000a. Portfolio Choice in the Presence of Background Risk. Economic Journal 110: 1-26.

Heaton J. and Lucas D. 2000b Portfolio Choice and Asset Prices: The Importance of Entrepreneurial Risk. Journal of Finance 55: 1163-1198.

Hodrick R.J. 1992. Dividend Yields and Expected Stock Returns: Alternative Procedures for Inference and Measurement. Review of Financial Studies 5: 357-386.

Hoffmann M. 2001. The relative Dynamics of Investment and the Current Account in the G7economies. Economic Journal 111: 148-168.

Hoffmann M. 2006a. Proprietary Income, Entrepreneurial Risk, and the Predictability of U.S. Stock Returns. unpublished manuscript University of Zurich.

Hoffmann M. 2006b. Balanced Growth and Empirical Proxies of the Consumption-Wealth Ratio. unpusblished manuscript University of Zurich.

Ioannidis C., Peel D.A. and Matthews K.P.G. 2006. Expected stock returns, aggregate consumption and wealth: some further evidence. Journal of Macroeconomics 28, 439-445. 
Johansen S. 1995. Likelihood-based inference in cointegrated vektor autoregressive models. Oxford University Press.

Kasa K. 1992. Common stochastic trends in international stock markets. Journal of Monetary Economics 29: 95-124.

Lane P.R. and Milesi-Ferretti G.M. 2001. The External Wealth of Nations: Measures of Foreign Assets and Liabilities for Industrial and Developing Nations. Journal of International Economics 55: 263-294.

Lettau M. and Ludvigson S. 2001. Consumption, Aggregate Wealth and Expected Stock Returns. Journal of Finance 56: 815-849.

Lettau M. and Ludvigson S. 2004. Understanding Trend and Cycle in Asset Values: Reevaluating the Wealth Effect on Consumption. American Economic Review 94: 276-299.

Lettau M. and Ludvigson S. 2005a. tay's as good as cay: Reply. Finance Research Letters 2:15-22.

Lettau M. and Ludvigson S. 2005b Expected returns and expected dividend growth. Journal of Financial Economics 76: 583-626.

Longin F. and Sonik B. 1995. Is the correlation in international equity returns constant: 19601990? Journal of International Money and Finance 14: 3-26.

Nagayasu J. 2006. Stocks, Consumption and Wealth: Some Evidence from the Tokyo Stock Exchange. discussion paper No. 1154, Department of Social Sciences and Management, University of Tsukuba.

Newey W.K. and West K.W. 1987. A simple, positive semidefinite, heteroskedasticity and autocorrelation consistent covariance matrix. Econometrica 55: 703-708.

Polkovnichenko V. 2004. Limited stock market participation and the equity premium. Finance Research Letters 1: 24-34.

Poterba J.M. and Summers L.H. 1988. Mean reversion in stock prices: evidence and implications. Journal of Financial Economics 22: 27-59.

Richards A.J. 1995. Comovements in national stock market returns: Evidence of predictability, but not cointegration. Journal of Monetary Economics 36: 631-654.

Rudd J. and Whelan K. 2006 Empirical proxies for the consumption-wealth ratio. Review of Economic Dynamics 9: 34-51.

Stock J.H. 1987. Asymptotic Properties Of Least Squares Estimators Of Cointegrating Vectors. Econometrica 55: 1035-1056.

Stock J.H. and Watson M.W. 1988. Testing for Common Trends. Journal of the American Statistical Association 83: 1093-1107. 
Stock J.H. and Watson M.W. 1993. A Simple Estimator of Cointegrating Vectors In Higher Order Integrated Systems. Econometrica 61: 783-820.

Tan A. and Voss G.M. 2003. Consumption and Wealth in Australia. Economic Record 79: 3956.

Tesar L.L. and Werner I.M. 1995. Home Bias and High Turnover. Journal of International Money and Finance 14: 467-492.

Vissing-Jörgensen A. (2002) Limited Stock Market Participation and the Elasticity of Intertemporal Substitution. Journal of Political Economy 110: 825-853. 


\section{Tables}

Table 1: Johansen Cointegration Test

\begin{tabular}{|c|c|c|c|c|}
\hline & \multicolumn{3}{|c|}{$\underline{\text { Critical Values Trace }}$} & \multirow[t]{2}{*}{$\underline{\text { Test Statistic Trace }}$} \\
\hline & $\underline{10 \%}$ & $\underline{5 \%}$ & $\underline{1 \%}$ & \\
\hline $\mathrm{r}=0$ & 44.4929 & 47.8545 & 54.6815 & 45.5429 \\
\hline $\mathrm{r}=1$ & 27.0669 & 29.7961 & 35.4628 & 14.0055 \\
\hline $\mathrm{r}=2$ & 13.4294 & 15.4943 & 19.9349 & 2.5366 \\
\hline$r=3$ & 2.7055 & 3.8415 & 6.6349 & 0.7659 \\
\hline
\end{tabular}

\begin{tabular}{|c|c|c|c|c|}
\hline & \multicolumn{3}{|c|}{ Critical Values L-Max } & $\underline{\text { Test Statistic L-Max }}$ \\
\hline & $\underline{10 \%}$ & $5 \%$ & $\underline{1 \%}$ & \\
\hline $\mathrm{r}=0$ & 25.1236 & 27.5858 & 32.7172 & 26.5361 \\
\hline $\mathrm{r}=1$ & 18.8928 & 21.1314 & 25.8650 & 11.4689 \\
\hline $\mathrm{r}=2$ & 12.2971 & 14.2639 & 18.5200 & 1.7707 \\
\hline$=3$ & 2.7055 & 3.8415 & 6.6349 & 0.7659 \\
\hline
\end{tabular}

$\begin{array}{ccc} & \underline{\mathrm{AIC}} & \underline{\mathrm{SIC}} \\ \mathrm{l}=1 & -22.0350 & -21.7791 \\ \mathrm{l}=2 & -21.9342 & -21.4224\end{array}$

Notes: The variables under consideration are non-durables and services consumption expenditure excluding expenditures on clothing and shoes, foreign stock holdings, the interaction term of foreign stock holdings and domestic asset wealth with the share of domestic in total asset wealth and labour income. All variables are measured at quarterly frequency. The sample starts second quarter 1952 and ends first quarter 2005. All variables are in natural logarithms, real, p.c. in 2000 chain weighted U.S. dollars. The Johansen test is performed under the assumption of an unrestricted constant but no time trend in the data. The Trace test tests the null hypothesis of $r$ cointegrating relations against the alternative of $p$, the number of variables in the tested system, cointegrating relations. The L-Max test tests the null of $r$ cointegrating relations against the alternative of $r+1$. AIC is the Akaike information criterion, SIC the Schwartz information criterion. 


\begin{tabular}{|c|c|c|c|c|}
\hline & $\overline{\Delta c_{t}}$ & $\overline{\Delta s s_{\mathrm{t}}}$ & $\Delta\left(\lambda_{\mathrm{t}}\left(d a w_{\mathrm{t}}-f_{s_{\mathrm{t}}}\right)\right)$ & $\overline{\Delta y_{\mathrm{t}}}$ \\
\hline$\Delta c_{\mathrm{t}-1}$ & $\underset{(3.3216)}{\mathbf{0 . 2 5 3 3}}$ & $1_{(1.1040)}^{1.7526}$ & $-{ }_{(-0.7524)}^{1.0757}$ & $\underset{(3.3527)}{\mathbf{0 . 5 2 2 7}}$ \\
\hline$\Delta f_{\mathrm{t}-1}$ & $\begin{array}{c}0.0073 \\
(0.3994)\end{array}$ & $-\underset{(-0.3217}{0.1228}$ & ${ }_{(0.6479)}^{0.2228}$ & ${ }_{(-1.2131)}^{0.0455}$ \\
\hline$\Delta\left(\lambda_{\mathrm{t}-1}\left(d a w_{\mathrm{t}-1}-f s_{\mathrm{t}-1}\right)\right)$ & $0_{(0.4073)}^{0.0081}$ & $\underset{(-0.6882)}{-0.2843}$ & ${ }_{(1.0877)}^{0.4046}$ & ${ }_{(-1.3731)}^{0.0557}$ \\
\hline$\Delta y_{\mathrm{t}-1}$ & $\underset{(2.3584)}{0.0942}$ & $\begin{array}{c}0.5390 \\
(0.6483)\end{array}$ & $-\underset{(-0.1918)}{0.1436}$ & $\underset{(-0.8229)}{-0.0672}$ \\
\hline$\hat{\boldsymbol{\beta}}^{\prime} \boldsymbol{x}_{t-1}$ & $-\underset{(-0.1955)}{0.0057}$ & $\underset{(4.6829)}{2.8203}$ & $-\underset{(-4.3522)}{2.3607}$ & $\begin{array}{c}0.0775 \\
(1.3113)\end{array}$ \\
\hline
\end{tabular}

Notes: This table reports VECM estimates for the cointegrated VAR consisting of nondurable consumption and services consumption expenditure excluding clothing and shoes, $c$, foreign stock holdings, $f s$, domestic asset wealth interacted with foreign equity holdings and the share of domestic asset wealth in asset wealth, $\lambda(d a w-f s)$, and labour income, $y$, for the sample period from the second quarter of 1952 to the first quarter of $2005 . \hat{\boldsymbol{\beta}}^{\prime} \boldsymbol{x}_{\boldsymbol{t}-1}$ is the cointegration residual obtained with the cointegration vector: $\hat{\beta}=\left[\begin{array}{llll}1 & -\underset{(8.77)}{0.22} f_{s_{t}} & -0.21 \lambda_{t}\left(\text { daw }_{t}-f s_{t}\right) & -\underset{(24.19)}{0.63 y_{t}}\end{array}\right]^{\prime}$ 
Table 3: Forecast error variance decompositions of the levels of the four cointegrated variables

\begin{tabular}{|c|c|c|c|c|c|c|c|c|}
\hline \multicolumn{9}{|c|}{$\alpha_{c}=\alpha_{y}=0$} \\
\hline & \multicolumn{2}{|c|}{$c_{\mathrm{t}+\mathrm{h}}-\mathrm{E}_{\mathrm{t}}\left(c_{\mathrm{t}+\mathrm{h}}\right)$} & \multicolumn{2}{|c|}{$f S_{\mathrm{t}+\mathrm{h}}-\mathrm{E}_{\mathrm{t}}\left(f S_{\mathrm{t}+\mathrm{h}}\right)$} & \multicolumn{2}{|c|}{$\begin{array}{c}\lambda_{\mathrm{t}+\mathrm{h}}\left(d a w_{\mathrm{t}+\mathrm{h}}-f s_{\mathrm{t}+\mathrm{h}}\right) \\
-\mathrm{E}_{\mathrm{t}}\left(\lambda_{\mathrm{t}+\mathrm{h}}\left(d a w_{\mathrm{t}+\mathrm{h}}-f s_{\mathrm{t}+\mathrm{h}}\right)\right)\end{array}$} & \multicolumn{2}{|c|}{$y_{\mathrm{t}+\mathrm{h}}-\mathrm{E}_{\mathrm{t}}\left(y_{\mathrm{t}+\mathrm{h}}\right)$} \\
\hline $\mathrm{h}$ & $\mathrm{P}$ & $\mathrm{T}$ & $\mathrm{P}$ & $\mathrm{T}$ & \multicolumn{2}{|l|}{$\mathbf{P}$} & $\mathrm{P}$ & $\mathrm{T}$ \\
\hline 1 & 1.0000 & 0.0000 & 0.1567 & 0.8433 & 0.2716 & 0.7284 & 1.0000 & 0.0000 \\
\hline 4 & 0.9999 & 0.0001 & 0.3645 & 0.6355 & 0.4624 & 0.5376 & 0.9994 & 0.0006 \\
\hline 8 & 0.9999 & 0.0001 & 0.5675 & 0.4325 & 0.6452 & 0.3548 & 0.9994 & 0.0006 \\
\hline 16 & 0.9999 & 0.0001 & 0.7959 & 0.2041 & 0.8332 & 0.1668 & 0.9994 & 0.0006 \\
\hline 24 & 0.9999 & 0.0001 & 0.8805 & 0.1195 & 0.9009 & 0.0991 & 0.9994 & 0.0006 \\
\hline \multicolumn{9}{|c|}{$\alpha_{c}$ and $\alpha_{y}$ estimated } \\
\hline & \multicolumn{2}{|c|}{$c_{\mathrm{t}+\mathrm{h}}-\mathrm{E}_{\mathrm{t}}\left(c_{\mathrm{t}+\mathrm{h}}\right)$} & \multicolumn{2}{|c|}{$f S_{\mathrm{t}+\mathrm{h}}-\mathrm{E}_{\mathrm{t}}\left(f s_{\mathrm{t}+\mathrm{h}}\right)$} & \multicolumn{2}{|c|}{$\begin{array}{c}\lambda_{\mathrm{t}+\mathrm{h}}\left(d a w_{\mathrm{t}+\mathrm{h}}-f s_{\mathrm{t}+\mathrm{h}}\right) \\
-\mathrm{E}_{\mathrm{t}}\left(\lambda_{\mathrm{t}+\mathrm{h}}\left(d a w_{\mathrm{t}+\mathrm{h}}-f s_{\mathrm{t}+\mathrm{h}}\right)\right)\end{array}$} & \multicolumn{2}{|c|}{$y_{\mathrm{t}+\mathrm{h}}-\mathrm{E}_{\mathrm{t}}\left(y_{\mathrm{t}+\mathrm{h}}\right)$} \\
\hline $\mathrm{h}$ & $\mathrm{P}$ & $\mathrm{T}$ & $\mathrm{P}$ & $\mathrm{T}$ & 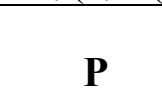 & $\mathrm{T}$ & $\mathrm{P}$ & $\mathrm{T}$ \\
\hline 1 & 0.9986 & 0.0014 & 0.1957 & 0.8043 & 0.3053 & 0.6947 & 0.9369 & 0.0631 \\
\hline 4 & 0.9984 & 0.0016 & 0.4603 & 0.5397 & 0.5509 & 0.4491 & 0.9620 & 0.0380 \\
\hline 8 & 0.9983 & 0.0017 & 0.6575 & 0.3425 & 0.7224 & 0.2766 & 0.9800 & 0.0200 \\
\hline 16 & 0.9884 & 0.0016 & 0.8264 & 0.1736 & 0.8616 & 0.1384 & 0.9891 & 0.0109 \\
\hline 24 & 0.9884 & 0.0016 & 0.8861 & 0.1139 & 0.9088 & 0.0912 & 0.9926 & 0.0074 \\
\hline
\end{tabular}

Notes: This table reports the forecast error variance share of the level of the cointegrating variables, consumption, $c$, foreign equity, $f_{S}$, domestic asset wealth interacted with foreign stock holdings and the share of domestic asset wealth in asset wealth, $\lambda($ daw- $f s)$ and labour income, $y$, that can be attributed to the combined three permanent shocks (columns "P") and the single transitory shock (columns "T"). The forecast horizon $\mathrm{h}$ is in quarters. 
Table 4: Long-horizon regressions of foreign stock market excess returns on U.S. cay

\begin{tabular}{|c|c|c|c|c|c|c|c|}
\hline & $\mathrm{h}=1$ & $\mathrm{~h}=4$ & $\mathrm{H}=8$ & $\mathrm{~h}=12$ & $\mathrm{~h}=16$ & $\mathrm{~h}=20$ & $\mathrm{~h}=24$ \\
\hline CND & $\begin{array}{l}1.03 \\
(1.45)\end{array}$ & $\begin{array}{l}2.97 \\
(1.17)\end{array}$ & $\underset{(1.71)}{5.54}$ & $\begin{array}{l}9.02 \\
(2.94)\end{array}$ & $\begin{array}{l}9.52 \\
(2.73)\end{array}$ & $\begin{array}{l}7.77 \\
(2.00)\end{array}$ & $\begin{array}{l}\mathbf{6} .32) \\
(2.69\end{array}$ \\
\hline $\mathrm{R}^{2}$ & 0.01 & 0.02 & 0.06 & 0.16 & 0.20 & 0.09 & 0.08 \\
\hline FRA & $\begin{array}{l}2.26 \\
(2.28)\end{array}$ & $\underset{(2.84)}{\mathbf{8 . 4 1}}$ & $\underset{(3.39)}{12.13}$ & $\underset{(5.00)}{19.01}$ & $\underset{(4.68)}{19.27}$ & $\underset{(3.37)}{14.09}$ & $\begin{array}{l}9.16 \\
(2.59)\end{array}$ \\
\hline $\mathrm{R}^{2}$ & 0.04 & 0.14 & 0.15 & 0.29 & 0.24 & 0.11 & 0.05 \\
\hline GER & $\begin{array}{l}1.77 \\
(2.08)\end{array}$ & $\begin{array}{l}6.23 \\
(2.55)\end{array}$ & $\underset{(2.04)}{\mathbf{8 . 3 6}}$ & $\underset{(2.05)}{12.22}$ & $\underset{(1.59)}{10.62}$ & $\begin{array}{l}4.61 \\
(0.73)\end{array}$ & $\begin{array}{l}0.62 \\
(0.17)\end{array}$ \\
\hline $\mathrm{R}^{2}$ & 0.03 & 0.09 & 0.09 & 0.15 & 0.09 & 0.01 & 0.01 \\
\hline ITA & $\begin{array}{l}1.42 \\
(1.36)\end{array}$ & $\begin{array}{l}7.54 \\
(2.02)\end{array}$ & $\underset{(2.33)}{14.42}$ & $\underset{(3.41)}{24.43}$ & $\underset{(3.25)}{26.54}$ & $\underset{(2.55)}{23.40}$ & $\underset{(1.85)}{20.28}$ \\
\hline $\mathrm{R}^{2}$ & 0.01 & 0.08 & 0.14 & 0.28 & 0.27 & 0.18 & 0.12 \\
\hline JPN & $\begin{array}{l}0.52 \\
(0.55)\end{array}$ & $\begin{array}{l}0.65 \\
(0.15)\end{array}$ & $\begin{array}{l}1.94 \\
(0.27)\end{array}$ & $\begin{array}{l}4.20 \\
(0.45)\end{array}$ & $\begin{array}{c}1.11 \\
(0.0 .12)\end{array}$ & $\underset{(-1.35)}{-9.45}$ & $-\underset{(-1.96)}{19.05}$ \\
\hline $\mathrm{R}^{2}$ & 0.00 & 0.00 & 0.00 & 0.00 & 0.00 & 0.02 & 0.10 \\
\hline UK & $\begin{array}{l}2.44 \\
(2.96)\end{array}$ & $\begin{array}{l}9.56 \\
(3.31)\end{array}$ & $\underset{(4.26)}{13.96}$ & $\underset{(4.94)}{19.31}$ & $\underset{(4.59)}{16.55}$ & $\underset{(3.18)}{12.87}$ & $\begin{array}{l}6.53 \\
(2.00)\end{array}$ \\
\hline $\mathrm{R}^{2}$ & 0.06 & 0.24 & 0.30 & 0.37 & 0.23 & 0.13 & 0.03 \\
\hline US & $\begin{array}{l}\underset{(3.55)}{2.08} \\
\end{array}$ & $\begin{array}{l}\mathbf{6 . 4 9} \\
(3.72)\end{array}$ & $\underset{(5.13)}{11.85}$ & $\underset{(4.36)}{16.38}$ & $\underset{(4.35)}{18.47}$ & $\underset{(3.89)}{17.91}$ & $\underset{(4.41)}{17.49}$ \\
\hline $\mathrm{R}^{2}$ & 0.07 & 0.20 & 0.34 & 0.44 & 0.45 & 0.34 & 0.31 \\
\hline
\end{tabular}

This table displays OLS estimates from regressions of the form

$$
r_{t+h}^{i, e}=\alpha_{h}+\beta_{h} c a y_{t}+\varepsilon_{t+h}
$$

with $r_{t+h}^{i, e}$ the $\log$ excess return on the MSCI stock index of country $i$ at time horizon $\mathrm{t}+\mathrm{h}$. Newey-West (Newey and West, 1987) corrected t-statistics appear below the regressor estimates. $\mathrm{R}^{2}$ reports the adjusted $\mathrm{R}^{2}$. Bold faces highlight significant estimates. The sample period runs from 1969Q4 to 2005Q1. 
Table 5: Long-horizon regressions of foreign stock market excess returns on U.S. cay and national dividend-price ratio

\begin{tabular}{|c|c|c|c|c|c|c|c|}
\hline & $\mathrm{h}=1$ & $\mathrm{~h}=4$ & $\mathrm{H}=8$ & $\mathrm{~h}=12$ & $h=16$ & $\mathrm{~h}=20$ & $\mathrm{~h}=24$ \\
\hline \multicolumn{8}{|c|}{ CND } \\
\hline cay & $\underset{(1.54)}{1.08}$ & $\begin{array}{l}2.50 \\
(0.96)\end{array}$ & $\begin{array}{l}4.79 \\
(1.51)\end{array}$ & $\begin{array}{l}8.61 \\
(2.66)\end{array}$ & $\begin{array}{l}9.45 \\
(2.52)\end{array}$ & $\begin{array}{c}7.90 \\
(1.76)\end{array}$ & $\begin{array}{l}7.47 \\
(2.31)\end{array}$ \\
\hline$d-p$ & $\begin{array}{l}0.00 \\
(0.06)\end{array}$ & $\begin{array}{l}0.08 \\
(0.89)\end{array}$ & $\underset{(1.19)}{0.12}$ & $\begin{array}{l}0.11 \\
(1.04)\end{array}$ & $\underset{(1.00)}{0.10}$ & $\begin{array}{l}0.24 \\
(1.44)\end{array}$ & $\begin{array}{l}0.27 \\
(1.58)\end{array}$ \\
\hline $\mathrm{R}^{2}$ & 0.00 & 0.03 & 0.08 & 0.19 & 0.23 & 0.17 & 0.16 \\
\hline \multicolumn{8}{|c|}{ FRA } \\
\hline cay & $\underset{(2.31)}{2.31}$ & $\underset{(2.92)}{8.62}$ & $\underset{(3.56)}{12.53}$ & $\underset{(5.76)}{20.03}$ & $\underset{(5.03)}{21.17}$ & $\underset{(3.59)}{17.11}$ & $\underset{(2.56)}{12.51}$ \\
\hline$d-p$ & $\begin{array}{l}0.00 \\
(0.21)\end{array}$ & $\begin{array}{l}0.03 \\
(0.68)\end{array}$ & $\begin{array}{l}0.06 \\
(0.78)\end{array}$ & $\begin{array}{l}0.11 \\
(1.29)\end{array}$ & $\begin{array}{l}0.16 \\
(1.63)\end{array}$ & $\underset{(1.37)}{0.22}$ & $\begin{array}{l}0.17 \\
(1.00)\end{array}$ \\
\hline $\mathrm{R}^{2}$ & 0.03 & 0.14 & 0.16 & 0.32 & 0.31 & 0.18 & 0.09 \\
\hline \multicolumn{8}{|c|}{ GER } \\
\hline cay & $\underset{(2.19)}{1.91}$ & $\begin{array}{l}6.96 \\
(2.84)\end{array}$ & $\begin{array}{l}9.98 \\
(2.51)\end{array}$ & $\underset{(2.73)}{14.81}$ & $\underset{(2.50)}{14.42}$ & $\underset{(1.59)}{10.72}$ & $\begin{array}{l}6.65 \\
(1.30)\end{array}$ \\
\hline$d-p$ & $\begin{array}{l}0.02 \\
(0.87)\end{array}$ & $\begin{array}{l}0.09 \\
(1.47)\end{array}$ & $\begin{array}{l}0.17 \\
(1.69)\end{array}$ & $\underset{(1.96)}{0.25}$ & $\begin{array}{l}\mathbf{0 . 3 7} \\
(2.60)\end{array}$ & $\underset{(2.60)}{0.44}$ & $\underset{(2.12)}{\mathbf{0 . 3 5}}$ \\
\hline $\mathrm{R}^{2}$ & 0.02 & 0.11 & 0.14 & 0.24 & 0.26 & 0.20 & 0.11 \\
\hline \multicolumn{8}{|l|}{ ITA } \\
\hline cay & $\begin{array}{l}1.48 \\
(1.36)\end{array}$ & $\begin{array}{l}7.39 \\
(1.96)\end{array}$ & $\underset{(2.16)}{13.69}$ & $\begin{array}{c}23.97 \\
(3.16)\end{array}$ & $\underset{(3.05)}{26.84}$ & $\underset{(2.34)}{23.68}$ & $\underset{(1.76)}{20.46}$ \\
\hline$d-p$ & $\underset{(045)}{0.01}$ & $\begin{array}{l}0.11 \\
(1.15)\end{array}$ & $\underset{(2.00)}{0.26}$ & $\begin{array}{l}0.18 \\
(1.95)\end{array}$ & $\begin{array}{l}0.05 \\
(0.48)\end{array}$ & $\begin{array}{l}0.02 \\
(0.08)\end{array}$ & $\underset{(-0.01)}{-0.00}$ \\
\hline $\mathrm{R}^{2}$ & 0.00 & 0.10 & 0.19 & 0.30 & 0.28 & 0.19 & 0.13 \\
\hline \multicolumn{8}{|l|}{$\mathrm{JPN}$} \\
\hline cay & $\begin{array}{l}1.17 \\
(1.29)\end{array}$ & $\begin{array}{l}3.60 \\
(0.95)\end{array}$ & $\begin{array}{l}7.52 \\
(1.32)\end{array}$ & 12.87 & $\underset{(1.58)}{12.34}$ & $\begin{array}{l}5.40 \\
(0.79)\end{array}$ & $\frac{-0.80}{(-0.10)}$ \\
\hline$d-p$ & $\begin{array}{l}0.04 \\
(1.95)\end{array}$ & $\underset{(2.13)}{0.18}$ & $\underset{(2.93)}{\mathbf{0 . 3 4}}$ & $\underset{(4.30)}{0.46}$ & $\underset{(5.27)}{0.58}$ & $\underset{(4.20)}{\mathbf{0 . 6 2}}$ & $\underset{(4.66)}{\mathbf{0 . 6 6}}$ \\
\hline $\mathrm{R}^{2}$ & 0.02 & 0.10 & 0.17 & 0.25 & 0.31 & 0.31 & 0.37 \\
\hline \multicolumn{8}{|l|}{ UK } \\
\hline cay & $\underset{(2.87)}{2.51}$ & $\begin{array}{c}9.64 \\
(3.37)\end{array}$ & $\underset{(4.86)}{14.36}$ & $\underset{(5.83)}{20.61}$ & $\underset{(4.89)}{18.57}$ & $\underset{(5.16)}{15.97}$ & $\underset{(6.16)}{12.00}$ \\
\hline$d-p$ & $\begin{array}{l}0.05 \\
(1.25)\end{array}$ & $\underset{(2.71)}{0.18}$ & $\begin{array}{l}\mathbf{0 . 2 9} \\
(3.48)\end{array}$ & $\underset{(4.55)}{\mathbf{0 . 5 0}}$ & $\underset{(6.21)}{0.64}$ & $\underset{(7.95)}{\mathbf{0 . 7 7}}$ & $\underset{(8.37)}{\mathbf{0 . 8 2}}$ \\
\hline $\mathrm{R}^{2}$ & 0.08 & 0.31 & 0.40 & 0.59 & 0.60 & 0.58 & 0.59 \\
\hline \multicolumn{8}{|l|}{ US } \\
\hline cay & $\underset{(3.63)}{2.11}$ & $\begin{array}{l}6.34 \\
(3.58)\end{array}$ & $\underset{(4.80)}{11.47}$ & $\begin{array}{c}15.89 \\
(4.01)\end{array}$ & $\begin{array}{c}18.06 \\
(4.17)\end{array}$ & $\begin{array}{c}17.57 \\
(3.91)\end{array}$ & $\underset{(4.92)}{18.08}$ \\
\hline$d-p$ & $\underset{(-0.02)}{-0.00}$ & $\begin{array}{l}0.02 \\
(0.41)\end{array}$ & $\begin{array}{l}0.06 \\
(0.61)\end{array}$ & $\underset{(1.12)}{0.12}$ & $\underset{(1.44)}{0.15}$ & $\begin{array}{l}\mathbf{0 . 2 5} \\
(3.32)\end{array}$ & $\begin{array}{c}\mathbf{0 . 2 9} \\
(2.80)\end{array}$ \\
\hline $\mathrm{R}^{2}$ & 0.08 & 0.20 & 0.36 & 0.48 & 0.54 & 0.44 & 0.40 \\
\hline
\end{tabular}


Notes: This table displays regressor estimates from regressions of the form

$$
r_{t+h}^{i, e}=\alpha_{h}+\beta_{h, c a y} c a y_{t}+\beta_{h, d p}\left(d_{t}^{i}-p_{t}^{i}\right)+\varepsilon_{t+h}
$$

with $r_{t+h}^{i, e}$ the $\log$ excess return on the MSCI stock index of country $i$ at time horizon $\mathrm{t}+\mathrm{h}$ and $\left(d_{t}^{i}-p_{t}^{i}\right)$ the respective national $\log$ dividend-price ratio. Newey-West (Newey and West, 1987) corrected t-statistics appear below the regressor estimates. $R^{2}$ reports the adjusted $R^{2}$. Bold faces highlight significant estimates. 


\begin{tabular}{lccccccc}
\hline \hline & CND & FRA & GER & ITA & JPN & UK & US \\
CND & 0.16 & & & & & & \\
FRA & 0.34 & 0.29 & & & & & \\
GER & 0.38 & 0.27 & 0.15 & & & & \\
ITA & 0.33 & 0.38 & 0.39 & 0.27 & & & \\
JPN & 0.08 & 0.08 & 0.06 & 0.09 & 0.01 & & \\
UK & 0.37 & 0.43 & 0.37 & 0.51 & 0.11 & 0.35 & \\
US & 0.42 & 0.56 & 0.37 & 0.61 & 0.23 & 0.49 & 0.40
\end{tabular}

Notes: This table presents the amount of covariation in three-year returns on the G7 stock markets explained by their exposure to the common, temporary stock market component reflected in cay for the sample period from the fourth quarter of 1973 to the first quarter of 2005 . 


\begin{tabular}{llllllll}
\hline \hline & CND & FRA & GER & ITA & JPN & UK & US \\
CND & 0.22 & & & & & & \\
FRA & 0.41 & 0.50 & & & & & \\
GER & 0.43 & 0.58 & 0.44 & & & & \\
ITA & 0.31 & 0.39 & 0.57 & 0.10 & & & \\
JPN & 0.27 & 0.36 & 0.31 & 0.43 & 0.05 & & \\
UK & 0.51 & 0.65 & 0.65 & 0.49 & 0.68 & 0.63 & \\
US & 0.49 & 0.63 & 0.55 & 0.65 & 0.55 & 0.67 & 0.58
\end{tabular}

Notes: This table presents the amount of covariation in three-year returns on the G7 stock markets explained by their exposure to the common, temporary stock market component reflected in cay for the sample period from the fourth quarter of 1989 to the first quarter of 2005 . 
Figure 1: Share of foreign equity in U.S. households' asset wealth (vertical axis) for the sample period from 1952 to 2005 (horizontal axis)

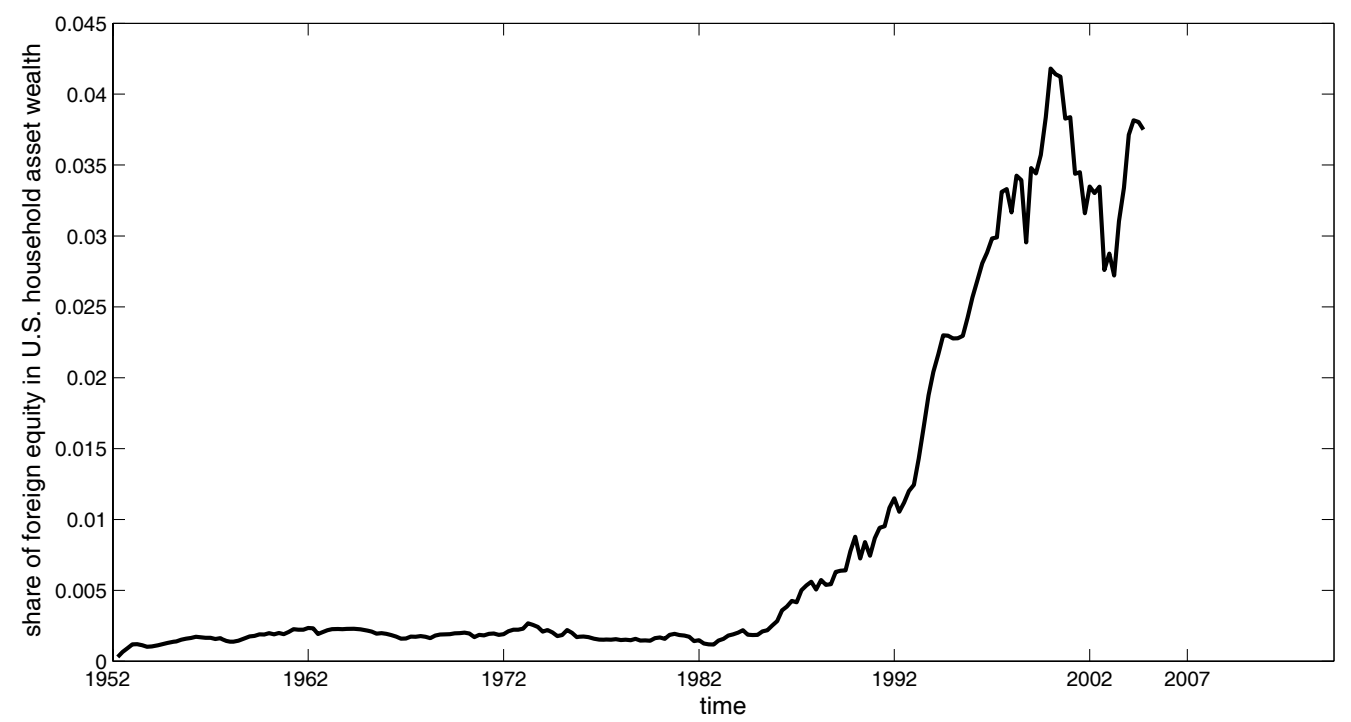

Figure 2: Realized three-year returns versus their fitted values obtained from univariate regressions on U.S. cay (Canada)

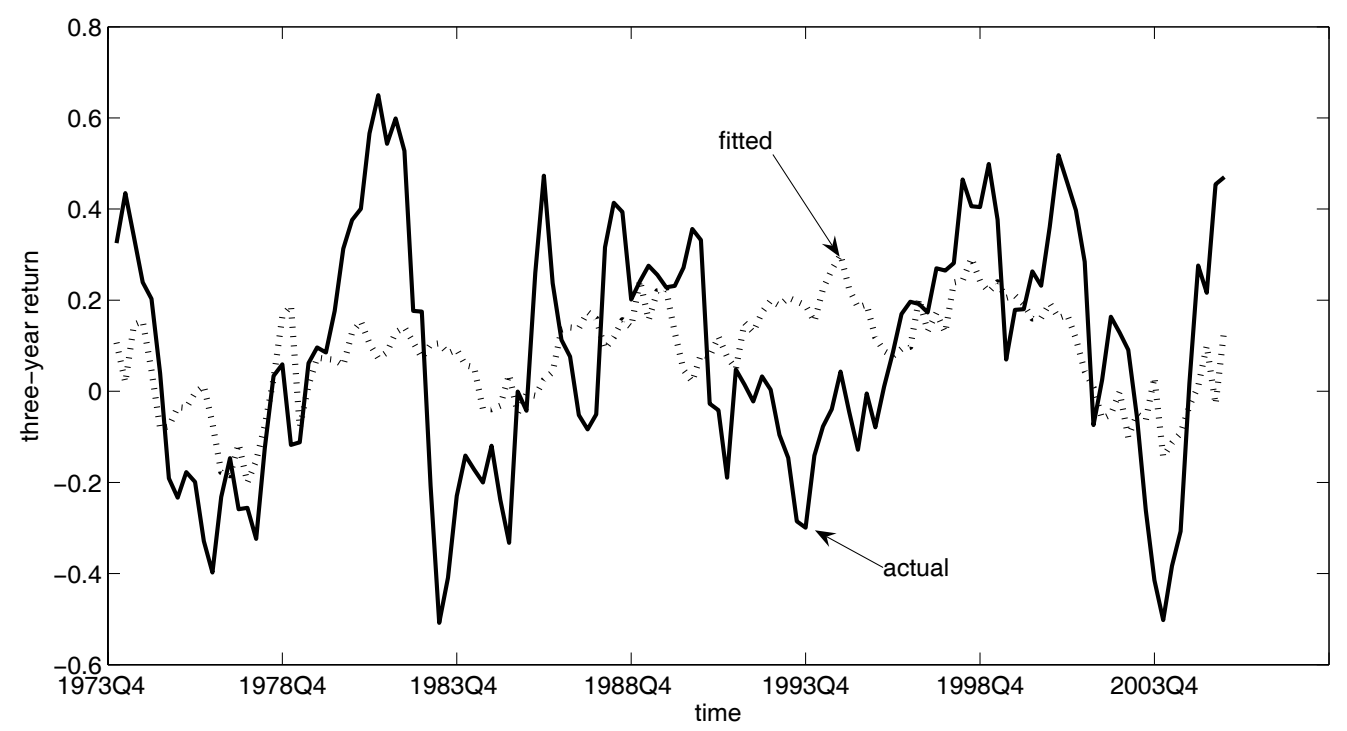


Figure 3: Realized three-year returns versus their fitted values obtained from univariate regressions on U.S. cay (France)

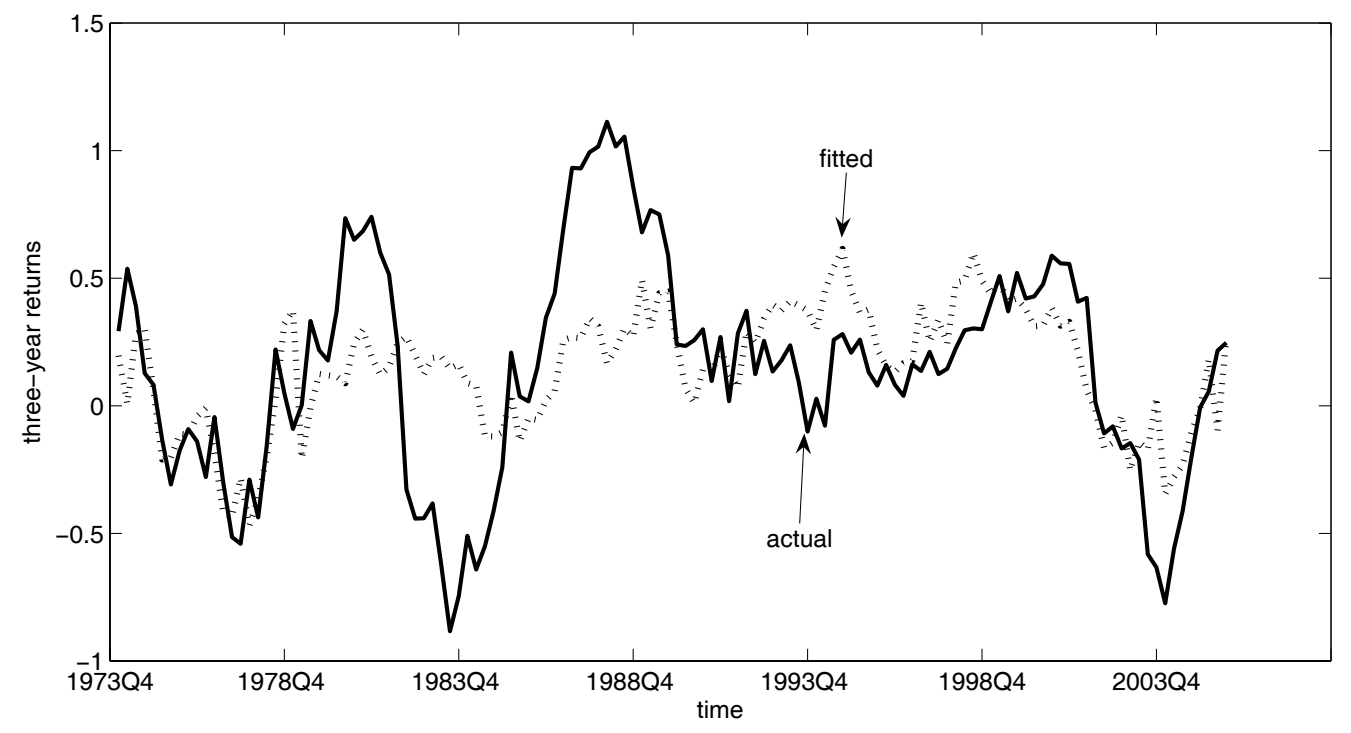

Figure 4: Realized three-year returns versus their fitted values obtained from univariate regressions on U.S. cay (Germany)

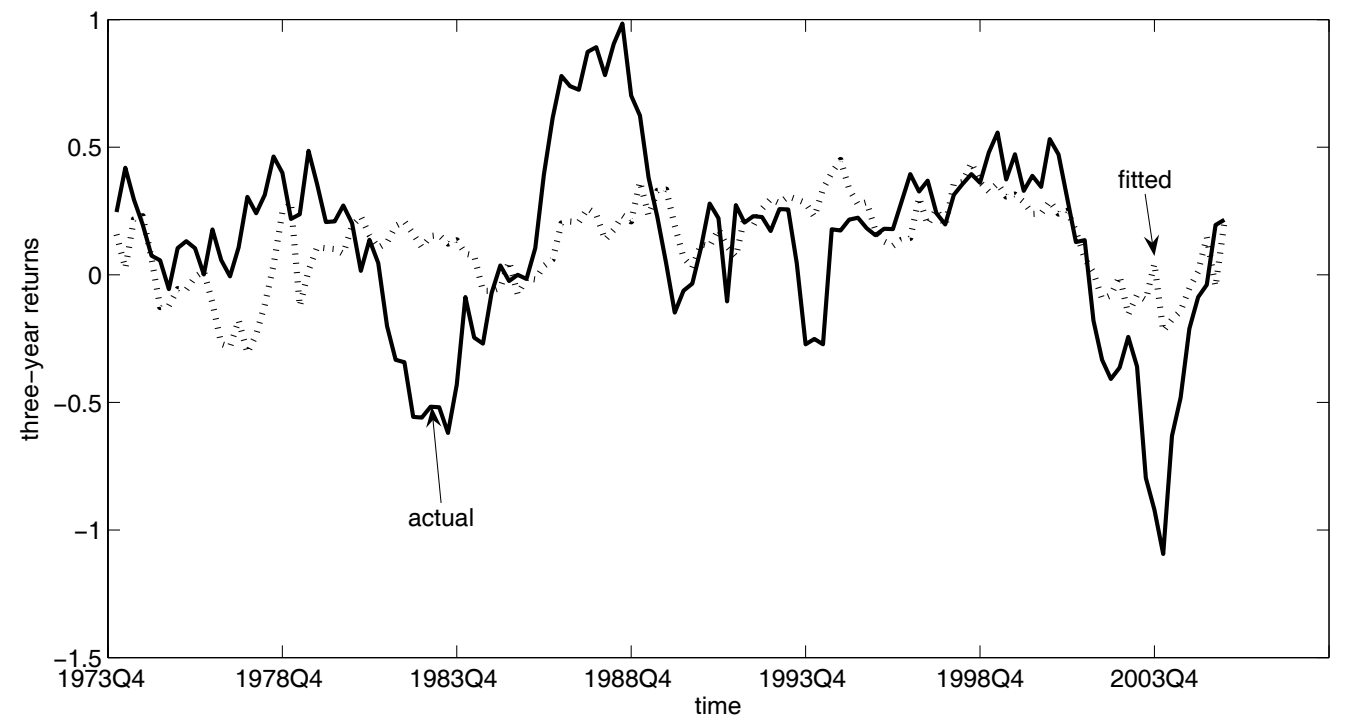


Figure 5: Realized three-year returns versus their fitted values obtained from univariate regressions on U.S. cay (Italy)

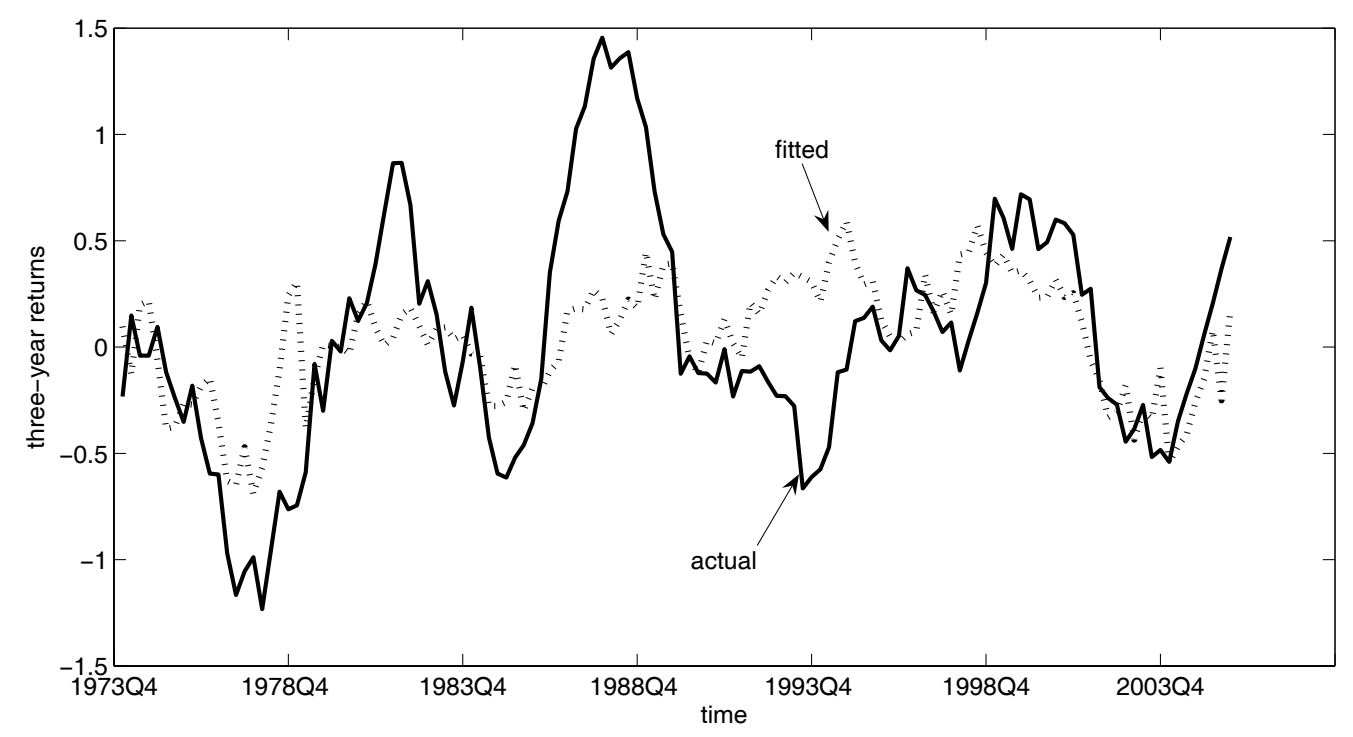

Figure 6: Realized three-year returns versus their fitted values obtained from univariate regressions on U.S. cay (Japan)

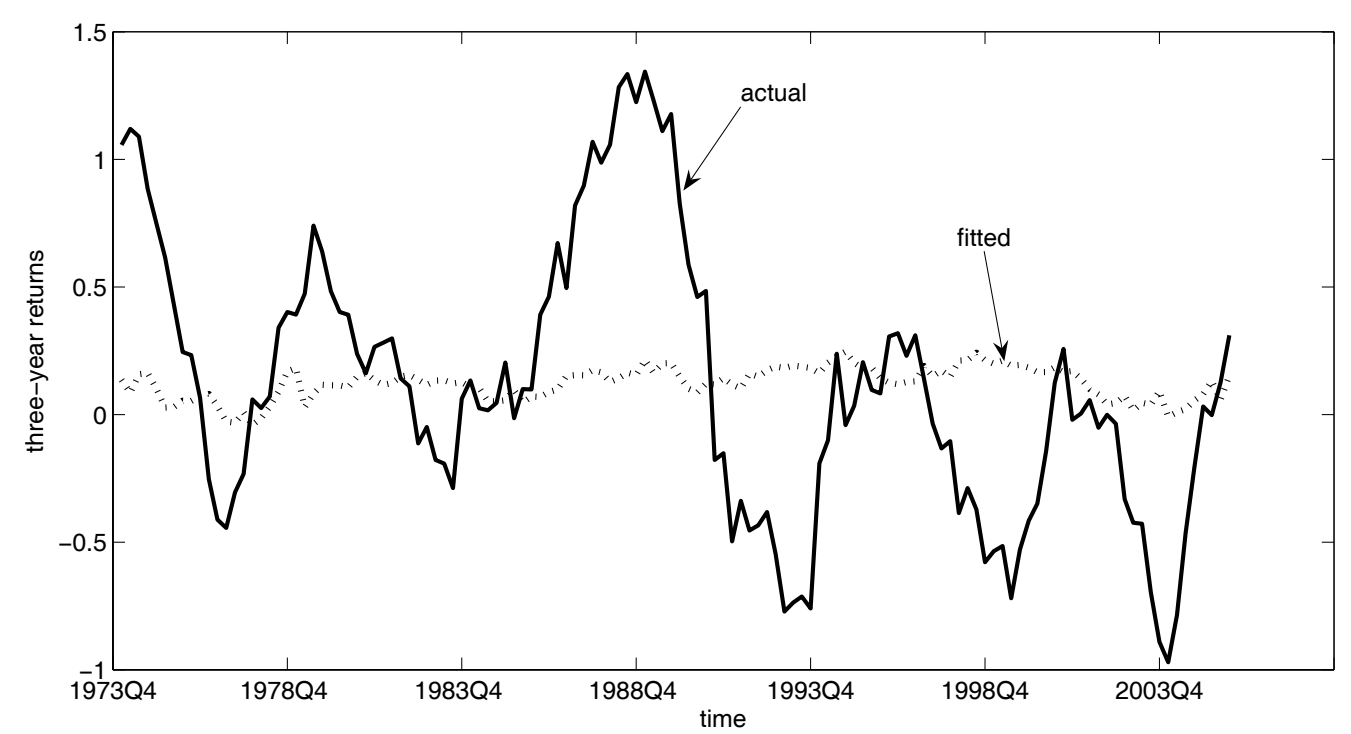


Figure 7: Realized three-year returns versus their fitted values obtained from univariate regressions on U.S. cay (United Kingdom)

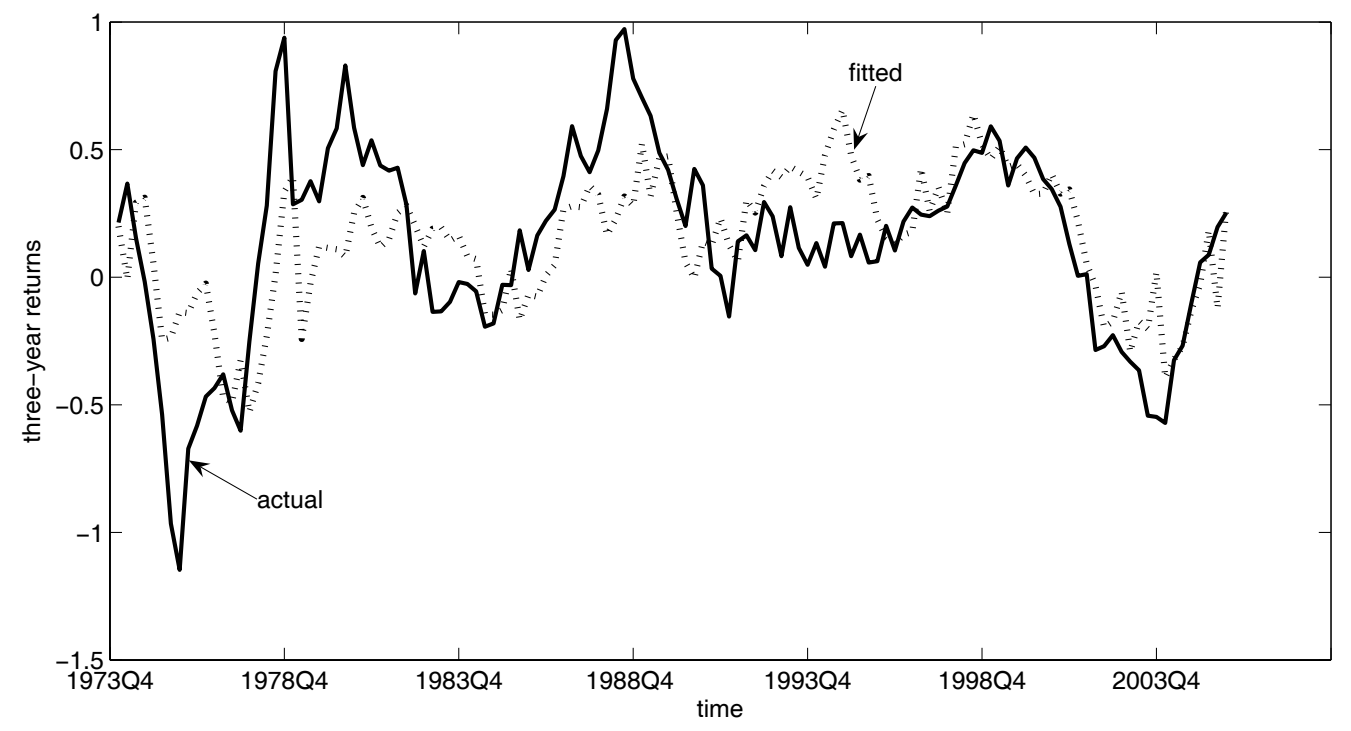

Figure 8: Realized three-year returns versus their fitted values obtained from univariate regressions on U.S. cay (United States)

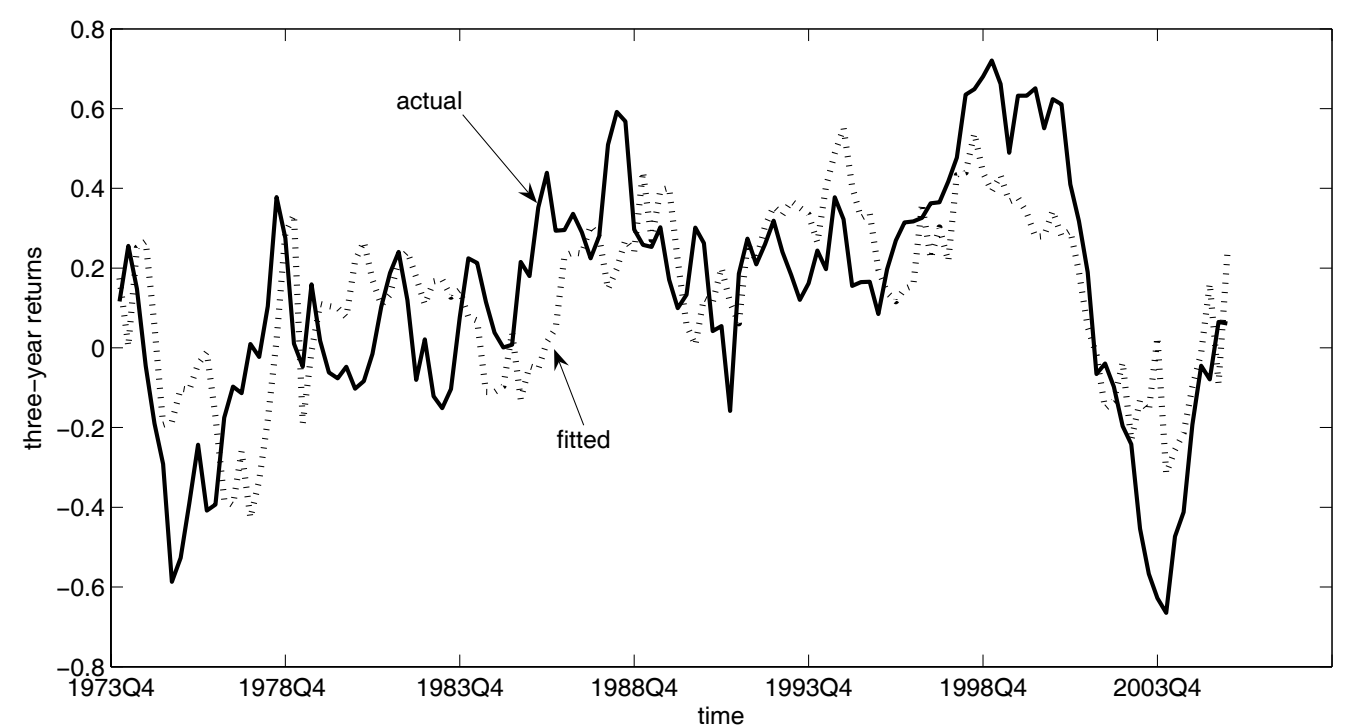

